\title{
Methane dynamics in the sediment and water column of Kiel Harbour (Baltic Sea)
}

\author{
R. Schmaljohann* \\ Fraunhofer-Institut für Atmosphärische Umweltforschung, Kreuzeckbahnstraße 19, \\ D-82467 Garmisch-Partenkirchen, Germany
}

\begin{abstract}
The dynamics of methane production and oxidation in the sediments of Kiel Harbour (Baltic Sea) were studied over a period of 2 yr. Expermentally determined rates of methanogenesis varied between 13 and $82 \mu \mathrm{mol} \mathrm{CH} \mathrm{Cm}_{4}^{-2} \mathrm{~h}^{-1}$ integrated over the top $30 \mathrm{~cm}$ of sediment. The zone of maximum production was between 20 and $30 \mathrm{~cm}$ depth. High potential rates could be induced in sulfatecontaning surface layers by the addition of molybdate, acetate or methanol, indicating competition with sulfate-reducing bacteria. The methane content in the sediment pore water increased from the surface to a seasonally varying depth of between 5 and $20 \mathrm{~cm}$, where sulfate concentrations approached zero and methane concentrations of 3 to $4 \mathrm{mM}$ were recorded. Aerobic methane oxidation rates in the surface sediment layer were in most cases higher than the methane flux expected to reach the sediment surface. Oxygen-depleted or anoxic conditions in the deep water, which frequently occurred during stratification periods in summer, resulted in methane gradients with increasing concentrations from the chemocline to the sediment. After recirculation of the water column in autumn in both years, unexpectedly high methane concentrations were also measured in the oxic water column of Kiel Harbour This coincided with very reduced conditions in the surface sediment that allowed measurable methane production in the 0 to $10 \mathrm{~cm}$ layer
\end{abstract}

KEY WORDS: Methane Methanogenesis Methane oxidation. Flux rates Sediment Baltic Sea

\section{INTRODUCTION}

Methanogenesis and methane oxidation have been studied in different areas of the Baltic Sea, showing that methane can, under certain conditions, play an important role in the carbon cycle of this environment and can accumulate to high concentrations in the sediment (Lein et al. 1981, Whiticar 1982, Berger \& Heyer 1990 Heyer et al. 1990, Bussmann 1994). During summer, the water column of the western Baltic Sea is characterized by a distinct stratification with a thermo-/halocline of between 10 and $15 \mathrm{~m}$ depth. These conditions frequently result in a depletion of oxygen in the deep water, especially in sheltered areas like the fjords and basins along the east coast of Schleswig-Holstein, Germany. Such basins were shown to contain high concentrations of methane and hydrogen sulfide in near-

\footnotetext{
- Present address: Instıtut für Meereskunde an der Universität
} Kıel, Düsternbrooker Weg 20, D-24105 Kıel, Germany surface sediment layers and in the anoxic deep water (Bansemir \& Rheinheimer 1974, Bussmann 1994).

It was the aim of this investigation to obtain data on the seasonal variation of methane concentrations in the sediment and in the water column, to determine the rates of methane production and oxidation in the sediment, and to analyze under which conditions an export of methane from the sediment to the water column occurred. For this purpose, 2 basins in Kiel Harbour were chosen, one of which was already investigated by Bansemir \& Rheinheimer (1974) in 1968-69 as to the production of hydrogen sulfide, and a 2 yr study of the methane budget during 1992 and 1993 was carried out.

\section{MATERIAL AND METHODS}

The investigation area in 1992 was a depression of the Kiel Harbour bottom near the HowaldtswerkeDeutsche Werft shipyard. It has an area of about $150 \times$ 
$300 \mathrm{~m}$ and a depth of $23 \mathrm{~m}$, making it the deepest site in Kiel Harbour with a mean depth of 11 to $15 \mathrm{~m}$ (Stn BL, corresponding to that sampled by Bansemir \& Rheinheimer 1974). This sampling site had to be changed at the beginning of 1993 , because a new dock was to be installed in the immediate vicinity. As a replacement for this site, another depression with a water depth of $21 \mathrm{~m}$, close to the Institut für Meereskunde, was found (Stn WK).

Sediment samples were taken at the deepest part of the depressions with the aid of an echosounder and by taking bearings from nearby landmarks. Sediment cores were obtained with a small gravity corer ('Rumohr-Lot') fitted with liners of $7.4 \mathrm{~cm}$ inner diameter. Salinity, temperature and oxygen content in the water column were measured in situ by combined probes (WTW, Weilheim, Germany) and water samples were taken with a 51 hydrographic sampler.

For the analysis of methane concentrations in the water column, $100 \mathrm{ml}$ glass bottles were filled without gas bubbles and stored at in situ temperature until arrival in the laboratory $(<1 \mathrm{~h})$. There two $5 \mathrm{ml}$ subsamples of each depth were injected into evacuated $16 \mathrm{mI}$ tubes, which were filled with $1.5 \mathrm{~g} \mathrm{NaCl}$ to give a saturated salt solution with the sample, and were sealed with a solid butyl rubber septum. After $1 \mathrm{~h}$ of shaking, this treatment resulted in an equilibrium where $99.5 \%$ of the methane was to be expected in the gas phase. This headspace methane concentration was determined by gas chromatography using a Packard Model 438A fitted with a flame ionization detector. Gases were separated on a $2 \mathrm{~m} \times 2 \mathrm{~mm}$ Hayesep $T$ column with $\mathrm{N}_{2}$ at a flow rate of $20 \mathrm{ml}$ min $^{-1}$ as carrier gas and an oven temperature of $100^{\circ} \mathrm{C}$.

The methane content of the sediment pore water was determined in a similar way: $5 \mathrm{ml}$ of sediment, taken with a cut-off syringe, was injected into a $20 \mathrm{ml}$ screw cap vial containing $5 \mathrm{ml}$ saturated $\mathrm{NaCl}$ solution and an additional $1.5 \mathrm{~g} \mathrm{NaCl}$. Thereafter, the vials were quickly sealed, shaken for $1 \mathrm{~h}$, and the gas content of the headspace was determined by gas chromatography. Methane concentrations per sediment volume were corrected for porosity to give concentrations in the pore water

The diffusive flux of methane from deeper sediment layers of the oxic sediment surface was calculated from the vertical profile of pore water methane concentrations using Fick's first law

$$
J_{D}=-\Phi D_{s}(\mathrm{~d} C / \mathrm{d} z)
$$

where $J_{D}$ is the diffusive flux $\left(\mu \mathrm{mol} \mathrm{CH}_{4} \mathrm{~m}^{-2} \mathrm{~d}^{-1}\right) ; \Phi$ is the porosity of the sediment $(0.88$ to 0.90 at $\mathrm{Stn} \mathrm{BL}$ and 0.84 to 0.89 at $\operatorname{Stn} W_{K}$ ); $D_{s}$ is the sediment diffusion. coefficient, calculated from the molar diffusion coeffi- cient $(D)$ by the empirical equation $D_{s}=D \Phi^{2}$ (Lerman 1979) using the temperature-dependent values for $D$ in Sahores \& Witherspoon (1970); and $\mathrm{d} C / \mathrm{d} z$ is the measured methane concentration gradient between the surface $(0$ to $2 \mathrm{~cm}$ ) and the sediment layer of methane production ( $\mu \mathrm{mol} \mathrm{l}^{-1} \mathrm{~cm}^{-1}$ ).

The rates of methane production in the sediment were measured by the following method: sediment samples were diluted 1:1 with oxygen-and sulfate-tree artificial seawater and most of the methane was stripped off with $\mathrm{N}_{2}$ (15 min). Aliquots of $40 \mathrm{ml}$, in triplicate for each sediment depth, were filled into $55 \mathrm{ml}$ crimp vials and sealed under $\mathrm{N}_{2}$. The vials were incubated under in situ temperature and in darkness for $2 \mathrm{~d}$, and the increase of methane in the headspace was measured by gas chromatography. Corrections were made for methane dissolved in the liquid phase at the different partial pressures in the gas phase. Controls with an addition of $20 \mathrm{mM} 2$-bromoethanesulfonate, a specific inhibitor of methanogenesis, were made to discriminate between biological activity and desorption of methane from particles. Only the part of methane release which could be inhibited by this compound was used for the calculations. In order to study the influence of sulfate reduction on methanogenesis and to measure potential rates of methanogenesis, an addition of sodium molybdate (final concentration $10 \mathrm{mM}$ ) was made to some of the samples to inhibit sulfate reduction, or an excess of substrates $(10 \mathrm{mM}$ methanol or $10 \mathrm{mM}$ acetate) was added to minimize the competition between the 2 groups of bacteria

The aerobic methane oxidation at the sediment surface was determined in suspensions of the upper $1 \mathrm{~cm}$ of sediment by measuring the decrease of methane during $24 \mathrm{~h}$ dark incubation under in situ temperature (modified after Heyer \& Suckow 1985). For this purpose, 1 or $2 \mathrm{ml}$ of surface sediment and $150 \mathrm{ml}$ of near-bottom seawater taken from the same station were filled into bottles and sealed without any gas space. By injection of different amounts of methane-saturated seawater, a range of concentrations was established, which made it possible to determine the dependence of the oxidation rate from the methane concentration, to estimate the rate at the in situ concentration and to calculate maximal rates, $V_{\max }$ according to Michaelis-Menten kinetics. The methane content in 3 bottles before and in 3 bottles after the incubation was measured using the same method as described above for water samples.

Sulfate concentrations in the sediment porewater were determined by single column ion chromatography (SCIC). Ions were separated on a $250 \times 4.6 \mathrm{~mm}$ silica-based column with phthalate buffer ( $\mathrm{pH} 4.9$ ) at a flow rate of $2 \mathrm{ml} \mathrm{min}^{-1}$. Sulfate was quantified by a conductivity detector. 
For density and porosity determinations, sediment samples of $50 \mathrm{ml}$ were weighed before and after drying for $24 \mathrm{~h}$ at $105^{\circ} \mathrm{C}$. Total dry organic matter was measured by weight loss on ignition at $500^{\circ} \mathrm{C}$.

Measurements of the redox potential were done by piercing a $\mathrm{Pt}$ versus $\mathrm{Ag} / \mathrm{AgCl}$ combination electrode stepwise from the surface into intact sediment cores. Readings were accepted after 2 to $10 \mathrm{~min}$, depending on constancy, and converted to potentials versus the standard hydrogen electrode according to temperature.

\section{RESULTS}

\section{General sediment characteristics}

The sediments of both stations are composed of very fine, muddy material, containing 71 to $75 \%$ (Stn BL) and 73 to $74 \%$ (Stn WK) water by weight throughout the sediment cores from the surface to $45 \mathrm{~cm}$ depth. Whereas this composition is very uniform at Stn BL, there are layers of fine sand at differing depths at Stn WK. The percentage of organic matter from dry weight was between 12 and $16 \%$ in the top $10 \mathrm{~cm}$ of Stn BL, decreasing to $10 \%$ at $40 \mathrm{~cm}$ depth. The sediment of Stn WK was poorer in organic matter $(8$ to $12 \%$, decreasing to $7-8 \%$ at $40 \mathrm{~cm}$ depth). There was a steep redox gradient within the first $2 \mathrm{~cm}$, which varied distinctly among seasons, but below $6 \mathrm{~cm}$ depth values were constantly between -200 and $-240 \mathrm{mV}$. Sediments of both stations gave off an intense odor of hydrogen sulfide and were colored black from 1 or $2 \mathrm{~cm}$ downwards. Oil residues were frequently found within the sediment cores. A colonization with macrofauna was not registered during the investigation period, with the exception of some small polychaetes during spring and early summer 1992.

\section{Methane and sulfate concentrations in the sediment}

The porewater concentrations of methane and sulfate for each sampling date are given in Fig. 1 (Stn BL) and Fig. 2 (Stn WK). Methane concentrations usually increased linearly or as a concave curve from the surface to a depth of between 5 and $22.5 \mathrm{~cm}$, where high values between 3 and $4 \mathrm{mM}$ were recorded. At this depth in most cases the curve levelled off, and below more or less constant concentrations or a slight increase followed. Methane contents in this range are below saturation $\left(5.1 \mathrm{mM}\right.$ for $15 \%$ salinity, $10^{\circ} \mathrm{C}$ and $23 \mathrm{~m}$ water depth); no methane bubbles were observed in freshly taken cores, but after short storage under atmospheric pressure occurred below 10 or $15 \mathrm{~cm}$ sediment depth.

A seasonality was found concerning the depth below which high methane concentrations were present in the sediment. Fig. 3 shows the depths where methane occurred at more than $2 \mathrm{mM}$ in the porewater. It is evident that mainly in late autumn and early winter, the near-surface sediment contained high amounts of methane. In late winter, this depth was about $20 \mathrm{~cm}$
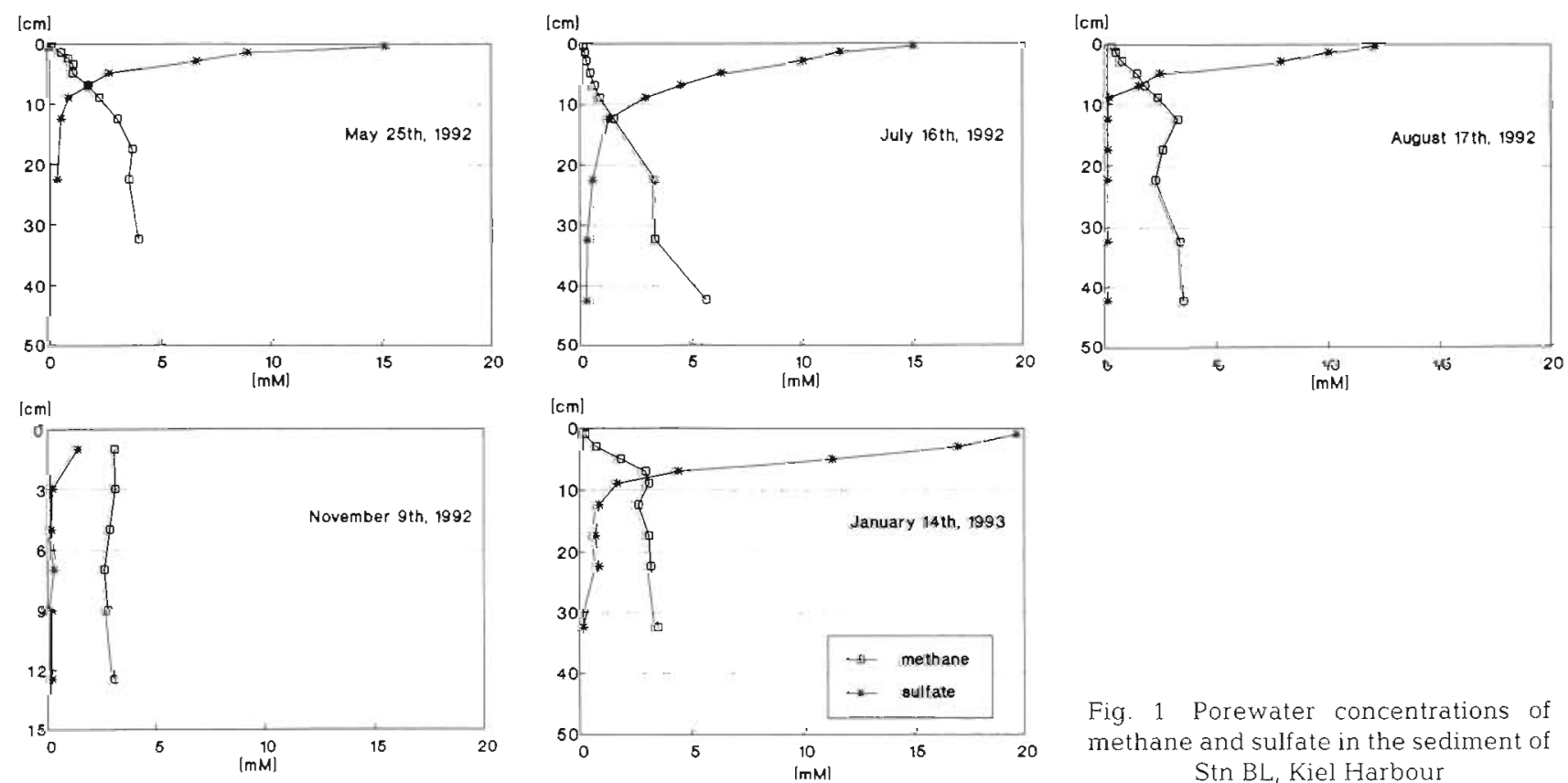

Fig. 1 Porewater concentrations of methane and sulfate in the sediment of Stn BL, Kiel Harbour 

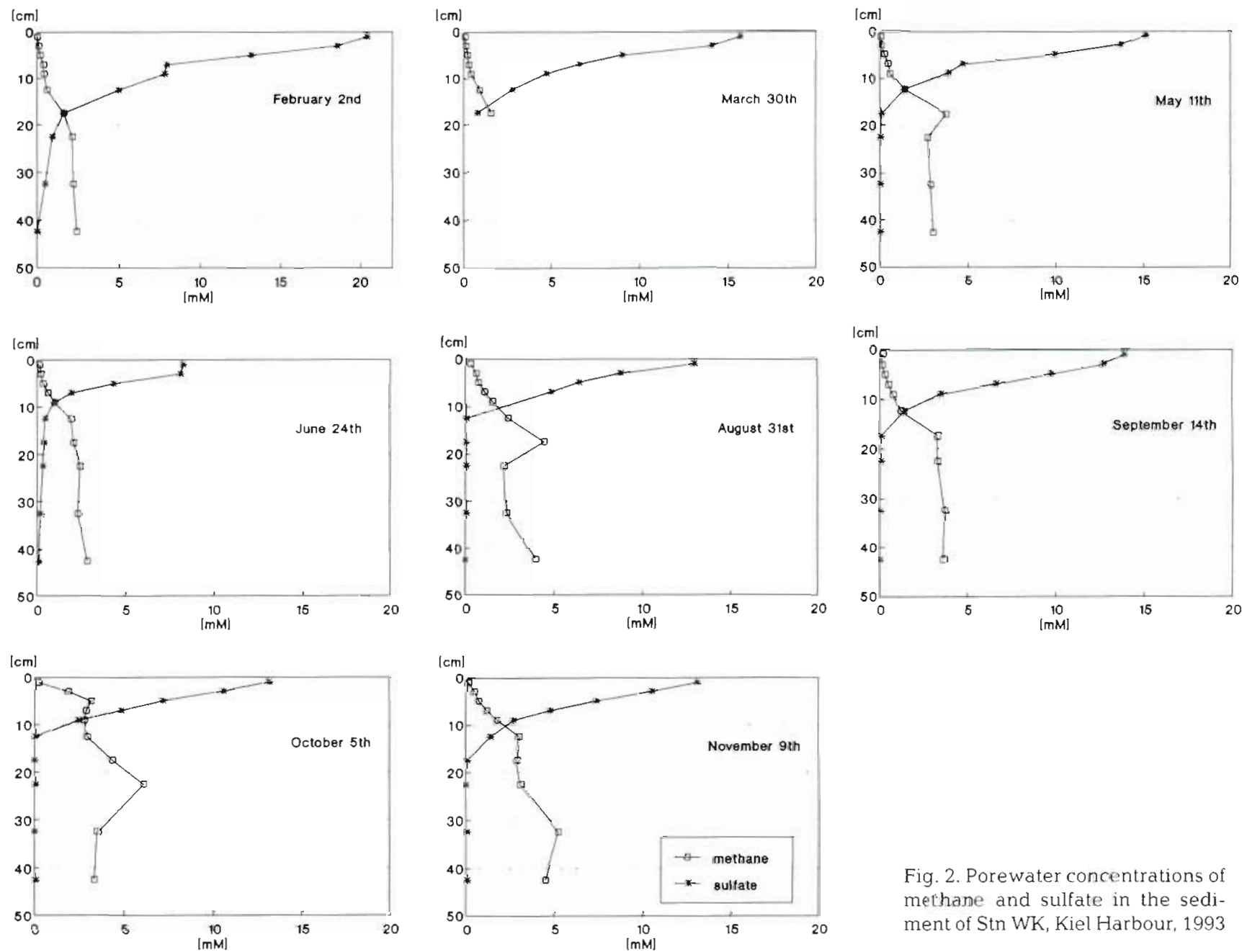

Fig. 2. Porewater concentrations of methane and sulfate in the sediment of Stn WK, Kiel Harbour, 1993

below the surface and ascended in summer during stagnation periods to 11 to $15 \mathrm{~cm}$ (Stn WK) and 8 to $15 \mathrm{~cm}$ (Stn BL) respectively. The times when methane

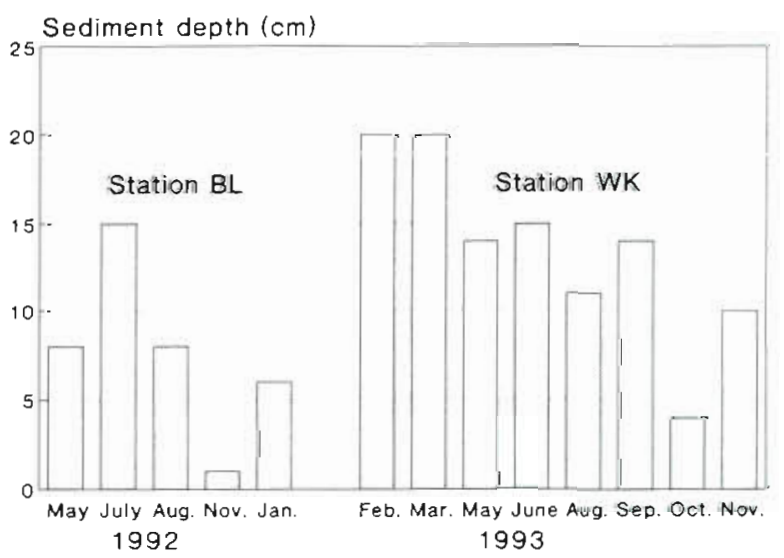

Fig 3. Sediment depths at stations BL and WK, where methane concentrations increased to more than $2 \mathrm{mM}$ occurred nearest the surface (November 9, 1992 and October 5, 1993) were also times with the highest methane concentrations in the water column (see Figs. $7 \& 8$ ).

The sulfate concentrations in the porewater during all seasons rapidly decreased with depth. Concentrations below $1 \mathrm{mM}$ were measured at only 2 to 13 $\mathrm{cm}$ (Stn BL) and 9 to $17 \mathrm{~cm}$ (Stn WK) respectively below the surface (Figs. 1 \& 2). High methane concentrations ( $>2 \mathrm{mM}$ ) generally occurred only in sediment layers that contained less than $2 \mathrm{mM}$ sulfate in the pore water. The levelling off of the methane profile below the zone of steady increase of concentrations always coincided with sulfate concentrations below $1 \mathrm{mM}$. In only 1 case (October 5, 1993) was a situation found where high methane production rates in sulfate-rich sediment layers ( 8 to $9 \mathrm{mM}$ ) were recorded, as can be seen by the methane concentration profile (Fig. 2) and by the measured production rate (Fig. 4B). 

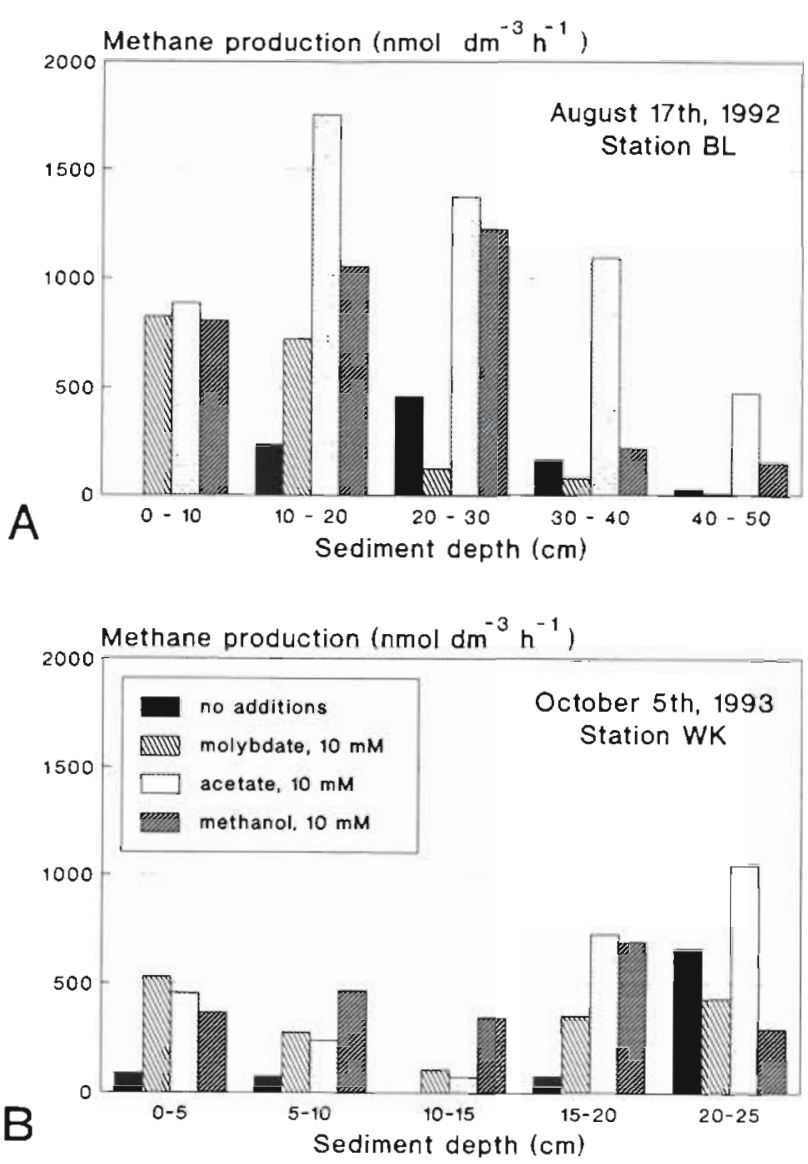

Fig. 4. Methane production in the sediment, determined in pure suspensions and with additions of molybdate, acetate or methanol. (A) The situation found throughout most of the year: (B) a typical autumn situation with methane production in pure suspensions within the top $10 \mathrm{~cm}$

\section{Methane production and flow rates in the sediment}

Methane production measured in sediment suspensions without any addition of inhibitors or substrates mainly occurred within the sediment layer 20 to $30 \mathrm{~cm}$ below the surface (Fig. 4A). Only low activities were recorded between 0 and $20 \mathrm{~cm}$ and below $30 \mathrm{~cm}$ depth. Integrated values for the sediment between 0 and $30 \mathrm{~cm}$ ranged between 12.6 and $81.8 \mu \mathrm{mol} \mathrm{CH}_{4} \mathrm{~m}^{-2} \mathrm{~h}^{-1}$ (Table 1). A clear seasonality or dependence on temperature cannot be concluded from the data, though a tendency for higher activities in autumn can be recognized. An addition of $10 \mathrm{mM}$ molybdate to exclude sulfate reduction resulted in high potential methane production rates in sulfate-containing near-surface sediment layers, but mostly had an inhibitory effect at greater sediment depths (Fig. 4A). A similarly advancing effect at all depths was achieved by the addition of methanol or acetate in excess, which compensated for the competition for substrates between methanogenic
Table 1 Calculated methane flux rates and experimentally determined methane production rates in sediments of Kiel Harbour: nd: no data

\begin{tabular}{|lccc|}
\hline $\begin{array}{l}\text { Sampling time } \\
\text { and station }\end{array}$ & $\begin{array}{c}\text { Diffusive methane flux } \\
\text { Depth } \\
(\mathrm{cm})\end{array}$ & $\begin{array}{c}\text { Rate } \\
\left(\mu \mathrm{mol} \mathrm{m} \mathrm{m}^{-2} \mathrm{~h}^{-1}\right)\end{array}$ & $\begin{array}{c}\text { Production rate } \\
\text { 0 to } 30 \mathrm{~cm} \mathrm{depth}^{-2}\end{array}$ \\
\hline Stn BL & & & \\
May 25, 1992 & $17.5-0.5$ & 77.1 & $\mathrm{nd}$ \\
Jul 16 & $22.5-0.5$ & 45.6 & 36.4 \\
Aug 17 & $12.5-0.5$ & 68.0 & 70.0 \\
Nov 9 & $1.0-0$ & 742 & 72.1 \\
Jan 14, 1993 & $9.0-1.0$ & 74.9 & 40.9 \\
& & & \\
Stn WK & & & \\
Feb 4, 1993 & $22.5-1.0$ & 18.0 & 12.6 \\
Mar 30 & $17.5-1.0$ & 15.5 & nd \\
May 11 & $17.5-1.0$ & 57.3 & nd \\
Jun 24 & $17.5-1.0$ & 33.8 & 16.1 \\
Aug 31 & $17.5-1.0$ & 71.1 & 29.3 \\
Sep 14 & $17.5-1.0$ & 54.7 & 49.4 \\
Oct 5 & $5.0-1.0$ & 202 & 81.8 \\
Nov 9 & $12.5-1.0$ & 52.0 & 49.3 \\
\hline
\end{tabular}

and sulfate-reducing bacteria. Acetate was a better substrate for methanogenesis than methanol, especially in deeper horizons.

Methane fluxes based on the concentration gradient between the site of methane production and the site of consumption at the sediment surface were calculated as a control for the experimentally determined methane production rates. If steady state conditions are assumed, the diffusive fluxes require a methane production rate of similar magnitude. Table 1 shows the vertical methane flux rates calculated for the depth range from the surface until the depth where the continuous increase of methane stopped. The highest flux rates were determined in situations with the steepest methane concentration gradients (November 9, 1992 and October 5, 1993). Rates were lowest during winter with a weakly developed methane gradient and, due to low temperatures, a small molar diffusion coefficient (D). A comparison between the calculated flux rates and experimentally determined production rates (Table 1) shows that both rates are in generally the same range, but in some cases, flux rates are clearly higher

\section{Aerobic methane oxidation rates at the sediment surface}

Fig. 5 shows the measured methane oxidation rates in the surface sediment layer. The maximal rates, $V_{\max }$, are potential rates measured at optimal methane and oxygen supply in diluted suspensions. They are a rela- 


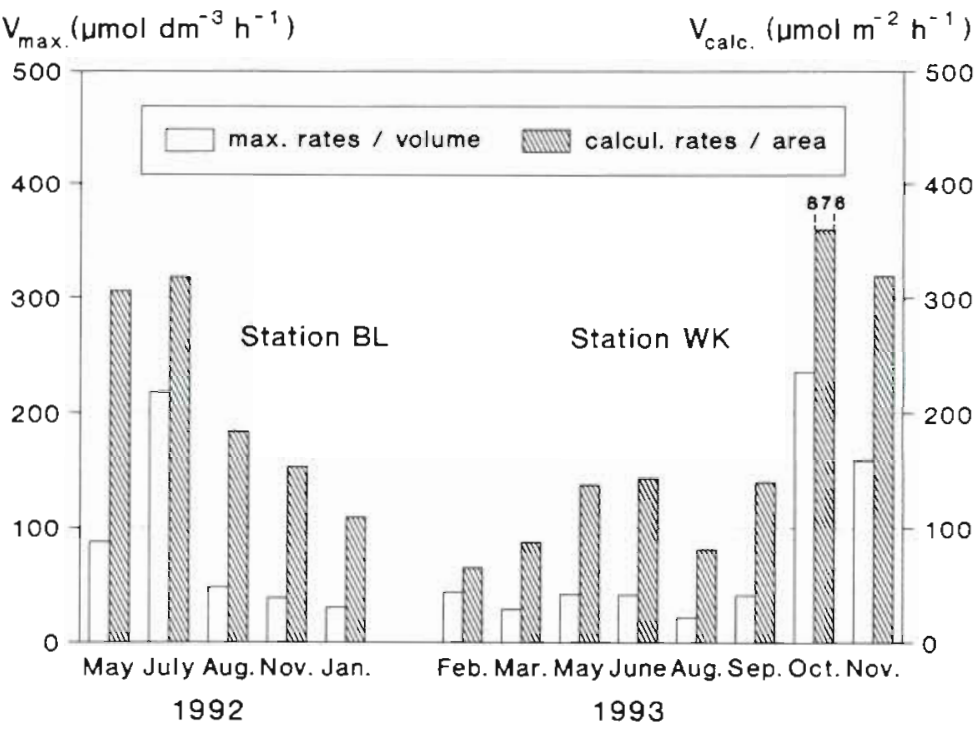

Fig. 5. Potential methane consumption rates in the sediment at Stns BL and WK. Maximum rates per volume of surface sediment $(0$ to $1 \mathrm{~cm})$ are given besides calculated rates for sediment area (assuming an oxygen penetration of $4 \mathrm{~mm}$ and using the measured methane concentrations of the 0 to $2 \mathrm{~cm}$ layer). During August 1992 and 1993, no oxygen was present in the near-bottom water and no actual aerobic methane oxidation was possible

\section{Physical and chemical conditions in the water column}

The distribution of methane in the water column depends largely on the stratification and the presence of oxygen. Figs. $7 \& 8$ show the temperature, salinity, oxygen and methane conditions in Kiel Harbour during 1992 and 1993. Temperatures in the nearbottom seawater varied between 3 and $17^{\circ} \mathrm{C}$; salinity varied between 15 and $22 \%$.

The year 1992 was characterized by a well-developed summer stagnation period, which was finished by a strong wind phase on September 14-15. At this time, a com plete mixing of the water column occurred, which led to a fish death due to upwelling of oxygen-poor deep water. The oxygen data (Fig. 7) show that on May 25 a marked chemocline was already established and that on August 17 and September 15, no oxygen was present in the deep water. The chemocline always coincided with a halothermocline at the same depth ( 7 to $12 \mathrm{~m}$ ) Methane concentrations increased from the

tive measure for the population size and activity of methanotrophic bacteria and enable a comparison between different sampling times. The in situ rates calculated per area take into account that aerobic methane oxidation is only possible in oxygen-containing sediment layers (assumed here to be the top $4 \mathrm{~mm}$ of sediment.) and are calculated for the average methane concentration of the 0 to $2 \mathrm{~cm}$ sediment horizon.

Fig. 6 gives an example of the dependence of the methane oxidation rate on the methane concentration in different seasons (summer and autumn). $V_{\max }$ values varied between 21.9 and $235 \mu \mathrm{mol} \mathrm{dm} \mathrm{dm}^{-3} \mathrm{~h}^{-1}$, though in 7 of 13 cases the activity ranged from 30 to $43 \mu \mathrm{mol}$ $\mathrm{dm}^{-3} \mathrm{~h}^{-1}$. Especially high activities were measured during summer stagnation at Stn BL (July 16, 1992) and during autumn 1993 at Stn WK. $V_{\text {in situ }}$ rates varied with 1 exception between 65 and $319 \mu \mathrm{mol} \mathrm{m} \mathrm{m}^{-2} \mathrm{~h}^{-1}(x=$ $170.4 \pm 93.0)$. A comparison of rates at different seasons shows that even at low temperatures (e.g. $3.2^{\circ} \mathrm{C}$ on February 4,1993 ) rates comparable to those in summer can be measured.

Assuming that the oxidation of $1 \mathrm{~mol}$ methane requires 2 mol oxygen, the oxygen consumption due to this process would range between 130 and $638 \mu \mathrm{mol}$ $\mathrm{m}^{-2} \mathrm{~h}^{-1}$ corresponding to $100-490 \mathrm{mg} \mathrm{O}_{2} \mathrm{~m}^{-2} \mathrm{~d}^{-1}$. Depending on physiological conditions of the methanotrophic bacteria and on the degree of methane oxidation (methanol, formaldehyde), the ratio of oxygen to methane may be less than 2, resulting in lower oxygen consumption. surface to the bottom at those times, where a chemocline was present, but stayed below $1 \mu \mathrm{M}$ (with the exception of a near-bottom sample from August 17). After mixing on September 15, homogeneously distributed high methane concentrations of about $1 \mu \mathrm{M}$ occurred throughout the water column. Extremely high concentrations (up to $8 \mu \mathrm{M}$ ) were recorded on November 9 , when after a long circulation period the

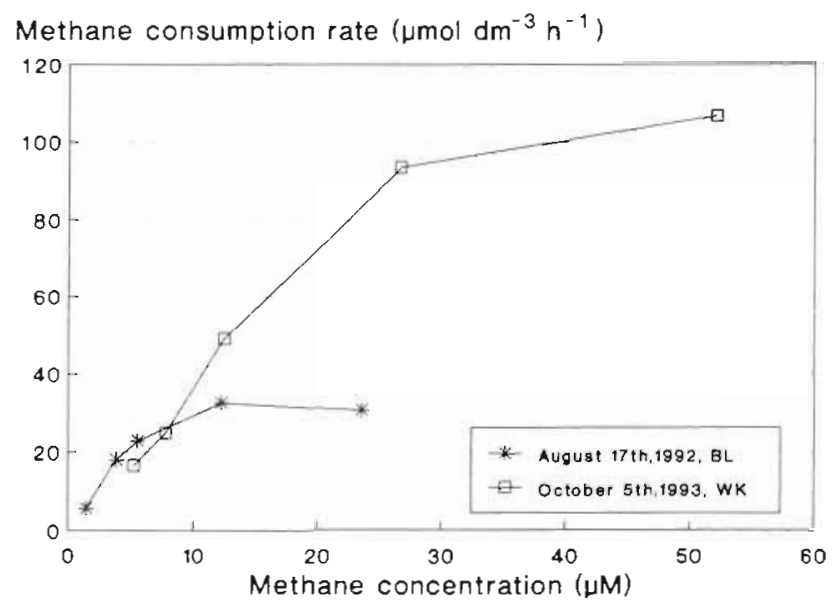

Fig. 6. Influence of methane concentration on methane consumption in the sediment. Data from August 1992 at Stn BL represent average activities, whereas exceptionally bigh activities are shown for Ortober 1993 at Str WK. In situ concentrations were $315 \mu \mathrm{M}$ in August 1992 and $168 \mu \mathrm{M}$ in October 1993 

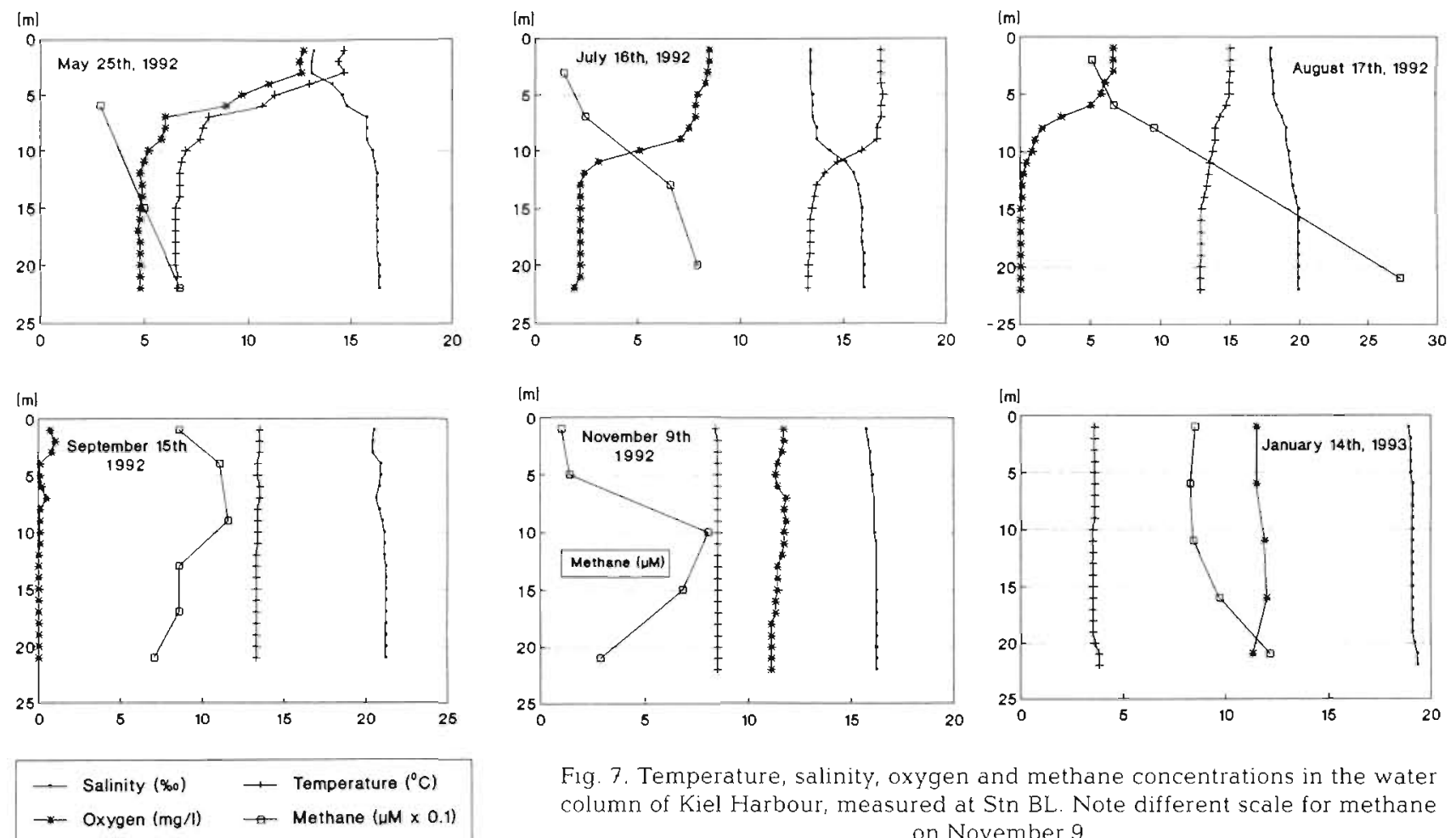

Fig. 7. Temperature, salinity, oxygen and methane concentrations in the water column of Kiel Harbour, measured at Stn BL. Note different scale for methane on November 9

water column was again saturated with oxygen and there was a high vertical methane flux in the surface sediment (Table 1).

In 1993, the oxygen supply in the deep water of Kiel Harbour was higher than in 1992. On only 2 sampling dates (August 19 and 31) was no oxygen present in the near-bottom water, and only during a period of 1 month was less than $3 \mathrm{mg} \mathrm{O} \mathrm{O}^{-1}$ measured (Fig. 8). Methane concentrations in the top $5 \mathrm{~m}$ of the water column ranged between 0.1 and $0.3 \mu \mathrm{M}$. In stagnation periods, the methane content increased towards the bottom, where values up to $1.1 \mu \mathrm{M}$ were recorded. As in autumn 1992 in a period with high methane concentrations in the surface sediment (October 5, 1993), unusually high amounts of methane were present throughout the oxic water column. Methane profiles during the stagnation period (August 3 to September 14) generally had a mid-depth maximum of between 10 and $14 \mathrm{~m}$ (Fig. 8).

\section{DISCUSSION}

From earlier investigations, it is known that the sediment of Stn BL in Kiel Harbour is a source of hydrogen sulfide penetrating into the water column during stagnation periods in summer. Hydrogen sulfide was shown to originate from intense sulfate reduction within the first 1 to $2 \mathrm{~cm}$ of the sediment. Up to $3.6 \mathrm{mg}$
$\mathrm{H}_{2} \mathrm{~S}^{-1}$ was found in the deep water (Bansemir \& Rheinheimer 1974).

In this study, it was shown that methane is also produced in high quantities in this sediment. The methane concentration profile in the water column suggests that there is a diffusion of methane from the sediment into the water, which during stagnation periods results in a gradient with high concentrations near the sediment surface and lower concentrations towards the chemocline. This was to be expected in periods with anoxic deep water because of the inhibition of the aerobic methane oxidation at the sediment surface. However, the finding of high concentrations of methane in the mixed, oxic water column during certain situations in autumn was surprising. There are at least 2 possible explanations for these methane dynamics:

(1) Intense aerobic decomposition in the surface layer after a period of retarded decomposition during stagnation could result in a more reduced sediment close to the surface and a corresponding higher sulfate reduction activity and sulfate depletion in this horizon. This, along with a higher availability of substrates, would favour methanogenesis in a layer where the competition with sulfate reducing bacteria would otherwise inhibit this process. This is supported by the steep sulfate concentration gradient with complete consumption of sulfate at $12 \mathrm{~cm}$ (October 5, 1993) and $3 \mathrm{~cm}$ depths (Novembe: 9, 1992) respectively. Simi- 
[m]

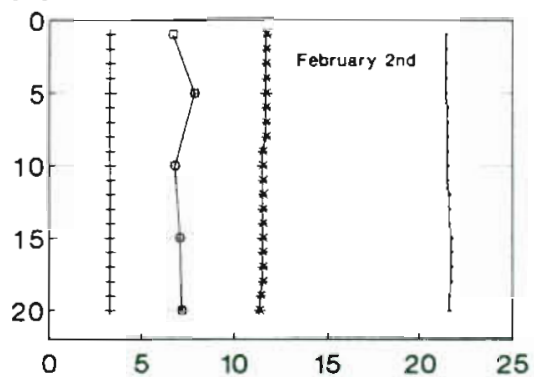

[m]



[m]

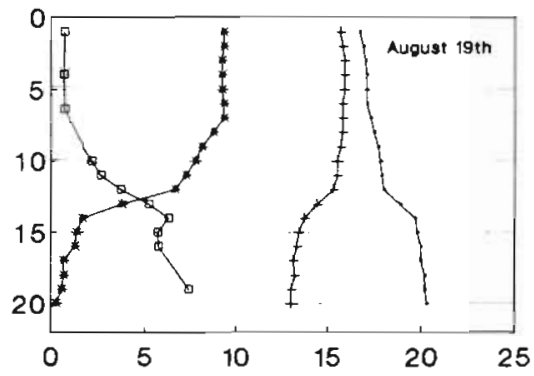

[m]

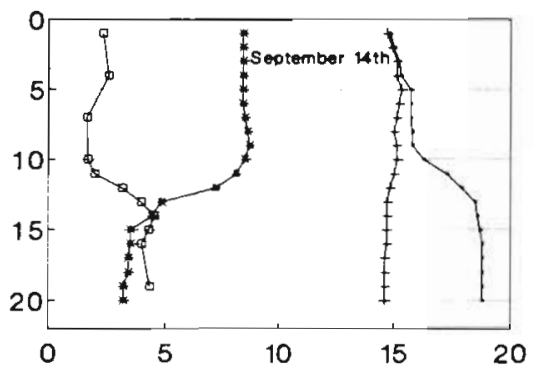

[m]

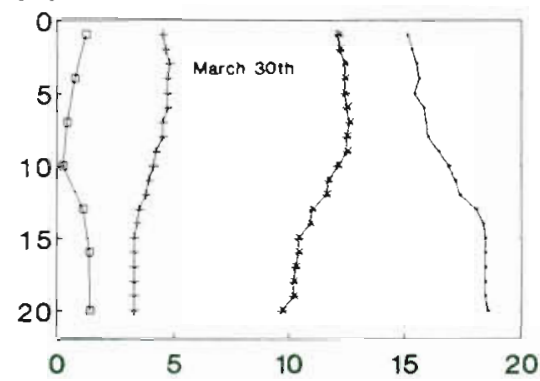

[m]

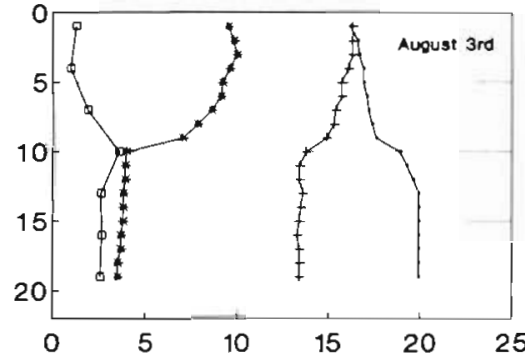

[m]

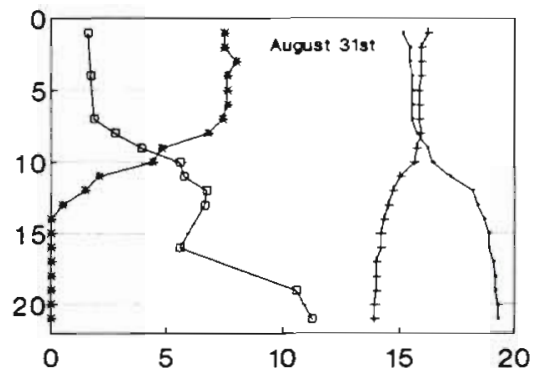

[m]

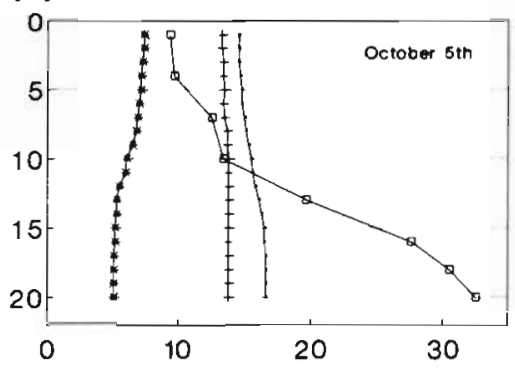

[m]



[m]

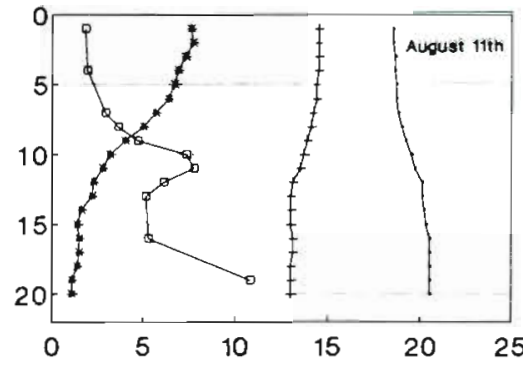

[m]

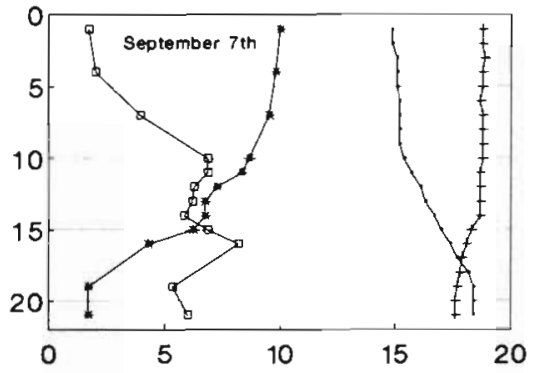

[m]

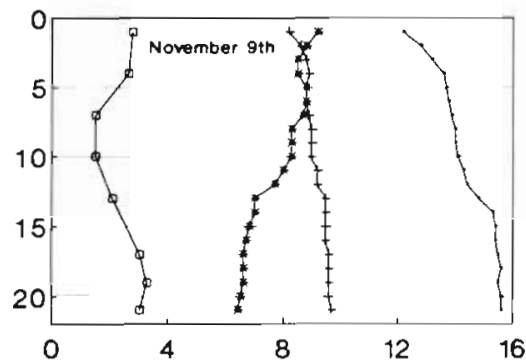

$\rightarrow$ Salinity $\left(\%_{0}\right)$
$\rightarrow$ Oxygen $(\mathrm{mg} / \mathrm{l}) \rightarrow$ Temperature $\left({ }^{\circ} \mathrm{C}\right)$
$\rightarrow$ Methane $(山 \mathrm{M} \times 0.1)$

Fig. 8. Temperature, salinity, oxygen and methane concentrations in the water column of Kiel Harbour, 1993, measured at Stn WK larly, Bansemir \& Rheinheimer (1974) reported high numbers of sulfate-reducing bacteria in the 0 to $1 \mathrm{~cm}$ horizon in November $\left(100000\right.$ cells $\left.\mathrm{cm}^{-3}\right)$, which decreased to 5000 cells $\mathrm{cm}^{-3}$ in March.

(2) After the breakdown of stratification and total mixing of the water column in late autumn, a phytoplankton bloom regularly occurs in Kiel Bight. This bloom has a high biomass of primary producers, but low numbers and activity of consumers able to mineralize the phytoplankton in the water column, therefore resulting in bulk sedimentation of organic matter to the bottom (Smetacek et al. 1984). Subsequent intense decomposition processes as described above would also result in very reduced surface sediment layers. 
Generally, the distribution of methanogenic activity with a maximum between 20 and $30 \mathrm{~cm}$ sediment depth, below the sulfate reduction zone, corresponds to the known pattern in marine sediments, where methanogenesis is inhibited in near-surface horizons by substrate competition with sulfate-reducing bacteria (Crill \& Martens 1983). An addition of substrates in excess that are used by methanogenic bacteria as well as by sulfate-reducing bacteria (acetate) or mainly by methanogenic bacteria (methanol) resulted in an increase of methane production, also in sulfate-containing horizons, compared with samples without any additions. These potential methane production rates show that the bacteria responsible for this process are present in the sulfate-containing layers but are not active under the experimental conditions. An inhibition of sulfate-reducing bacteria with molybdate also induced methanogenesis in the near-surface sediment, but frequently had no effect at deeper horizons, indicating that competition with sulfate-reducing bacteria was the reason for the lack of methanogenic activity there. Thus, these sediments differ clearly from salt marsh or shallow water sediments, where methane production frequently takes place within the top $10 \mathrm{~cm}$, often simultaneously with sulfate reduction and by using non-competitive substrates like methylamines (Oremland et al. 1982, King et al. 1983, Heyer et al. 1990).

The methane production rates measured by the applied method were net rates. In contrast to methods using single labelled substrates like ${ }^{14} \mathrm{C}$-acetate or $\mathrm{H}^{14} \mathrm{CO}_{3}^{-}$, it records methane production by all possible substrates. However, anaerobic methane oxidation cannot be excluded and possibly reduces the net release of methane. According to Iversen \& Jørgensen (1985), anaerobic methane oxidation can be expected at a sediment depth where sulfate and methane are present in equimolar concentrations. This depth in the sediments studied in Kiel Harbour lies between 7 and $12.5 \mathrm{~cm}$, at the crossover of the sulfate and methane concentration profiles (Figs. $1 \& 2$ ). The process of anaerobic methane oxidation may also be the reason for the concave nature of the methane pro- files between the zone of production and the sediment surface, and for the sharp decrease in methane concentrations above the production zone. Applying diffusion models, such a curve can only be explained by an anaerobic consumption of methane, and several authors have used the shape of the methane profile in sediments to calculate anaerobic methane oxidation rates (Barnes \& Goldberg 1976, Reeburgh 1976 , Martens \& Berner 1977). A possible undervaluation of the true methane production rates might also be the reason for the differences between the calculated methane flux rates and the measured production rates in this study. It is known that sediment slurries, as were used for these experiments, often have lower activites than intact cores because sediment-microbial associations are disturbed. Another reason for this might be that the integrated values for methanogenesis given in Table 1 refer to a sediment depth from 0 to $30 \mathrm{~cm}$. In some longer cores that were investigated, however, low activity was also measured beneath that depth.

Methane production rates determined in this study ranged from 13 to $82 \mu \mathrm{mol} \mathrm{m} \mathrm{m}^{-2} \mathrm{~h}^{-1}$. These rates, measured at in situ temperatures between 3 and $15^{\circ} \mathrm{C}$, are comparable to those of similar coastal marine habitats, which at similar depths and temperatures exhibit rates of between 0.5 and $160 \mu \mathrm{mol} \mathrm{m} \mathrm{m}^{-2} \mathrm{~h}^{-1}$ (Table 2). The sediments investigated in Kiel Harbour clearly have less activity than many shallow, light exposed, subtidal or salt marsh sediments, but produce more methane than seen in marine sediments of greater depth (Heyer 1990).

The aerobic methane oxidation rates determined in the 0 to $1 \mathrm{~cm}$ surface sediment have to be interpreted as potential rates. They are dependent on the actual oxygen and methane conditions in the first few millimeters of sediment, which are very difficult to determine in situ. The 'in situ' rates calculated for an oxygen penetration depth of $4 \mathrm{~mm}$ and the methane concentration measured in the 0 to $2 \mathrm{~cm}$ horizon (Fig. 5) are in most cases higher than the methane production and methane flux rates. Thus, the sediment surface should be an effective barrier for the

Table 2. Comparison of methane production rates in shallow water marine sediments of different geographical ongin

\begin{tabular}{|c|c|c|c|c|}
\hline Location & $\begin{array}{l}\text { Water depth } \\
\qquad(\mathrm{m})\end{array}$ & $\begin{array}{l}\text { Sediment depth } \\
(\mathrm{cm})\end{array}$ & 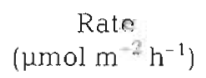 & Source \\
\hline Port Moller (Bering Sea) & $3-30$ & $0-10$ & 160 & Griffiths et al. (1983) \\
\hline Saanich Inlet (British Columbia, Canada), & 220 & $30-120$ & 2.3 & Kuivila et al (1990) \\
\hline Cape Lookout Bight (North Carolina, USA) & $10-20$ & $0-35$ & $20-40$ & Crill \& Martens (1983) \\
\hline Swedish west coast & $8-13$ & $0-5$ & 0.5 & Gunnarsson \& Rönnow (1982) \\
\hline Gulf of Riga (Baltic Sea) & 54 & $0-200$ & 129 & Lein et al. (1981) \\
\hline Kiel Harbour (Baltic Sea) & $20-23$ & $0-30$ & $16-82$ & This study \\
\hline
\end{tabular}


vertical methane flux from the sediment to the water column. However, regarding the methane concentrations in the water, it has to be concluded that an export of methane from the sediment takes place, at least in stagnation periods with poor oxygen supply in the deep water and a stratified water column, but also during autumn, when the water column is mixed again. Even in winter and spring, methane concentrations in Kiel Harbour water range between 0.05 and $1.2 \mu \mathrm{M}$ and thus are about 2 orders of magnitude higher than in open ocean surface waters 10.0018 to $0.0031 \mu \mathrm{M}$; Heyer 1990). Therefore, throughout the year, a diffusion of methane from the sediment to the water column has to be postulated. An emission of methane by release of gas bubbles, as can be seen in many other harbour basins, has never been observed and cannot be expected because of concentrations in the sediment below the saturation point. As the harbour water is oversaturated with methane with respect to air, there will be also a methane flux from the water to the atmosphere.

An oxidation of methane in the water column cannot be excluded; especially during stagnation periods, this process might be active at the chemocline. Attempts to measure this activity with the method also applied for sediment methane oxidation did not reveal any methane consumption, probably because the sensitivity of this method was not sufficient.

Aerobic methane oxidation at the sediment surface will contribute significantly to oxygen consumption at this site. Though this process was not measured directly, an estimation of the proportion of oxygen needed for aerobic methane oxidation shall be carried out. Taking the average methane flux rates as a basis (1.24 $\pm 0.52 \mathrm{mmol} \mathrm{m} \mathrm{m}^{-2} \mathrm{~d}^{-1}$ for all samplings except the extreme autumn values of November 9, 1992 and October 5, 1993), the amount of oxygen required to oxidize all methane diffusing to the sediment surface can be calculated. Assuming a consumption of $2 \mathrm{~mol}$ $\mathrm{O}_{2}$ for the complete oxidation of 1 mol $\mathrm{CH}_{4}$ to $\mathrm{CO}_{2}$, $2.48 \pm 1.04 \mathrm{mmol} \mathrm{O}_{2} \mathrm{~m}^{-2} \mathrm{~d}^{-1}$ would be required. These data can be compared to the total oxygen uptake data determined by Pollehne (1986) in intact sediment cores from a similar station in Kiel Bight at $28 \mathrm{~m}$ water depth; he found mean oxygen uptake rates of $8.88 \pm$ $4.78 \mathrm{mmol} \mathrm{m} \mathrm{m}^{-2} \mathrm{~d}^{-1}$ as an average of 11 sampling times between March and November. Accordingly, a complete aerobic oxidation of the methane produced in the sediment of the investigated stations in Kiel Harbour would consume about $28 \%$ of the total oxygen uptake. The data of this study do not allow the determination of which proportion of the methane produced is actually oxidized at the sediment surface, but show that aerobic methane oxidation is an important oxygen-consuming process in this environment.
Acknowledgements. This research was supported by grant 03F0044B from the Bundesministenum fur Forschung und Technologie. I thank the Institut furr Meereskunde, Kiel, and the Fraunhofer-Institut fur Atmospharische Umweltforschung Garmisch-Partenkirchen, for providing laboratory and ship facilities and for administrative help. I am grateful to $D r J$. Heyer for advice in methods and critical discussion of the data, and to Dr L. Piker for assistance in sulfate analysis. Thanks also to the crews of the research vessels 'Sagitta' and 'Littorina' for help with the collection of samples

\section{LITERATURE CITED}

Bansemir K, Rheinheimer G (1974) Bakteriologische Untersuchungen über die Bildung von Schwefelwasserstoff in einer Vertiefung der inneren Kieler Förde. Kieler Meeresforsch 30:91-98

Barnes RO, Goldberg ED (1976) Methane production and consumption in anoxic marine sediments. Geology 4: $297-300$

Berger U, Heyer J (1990) Distribution and activity of methanotrophic bacteria in a brackish water ecosystem. Limnologica 20:141-144

Bussmann I (1994) Verteilung und Steuergrößen der Aktivität Methan-oxidierender Bakterien in Randmeeren des Nordatlantiks. PhD thesis, Kiel University

Crill PM, Martens CS (1983) Spatial and temporal fluctuations of methane production in anoxic coastal marine sediments. Limnol Oceanogr 228:1117-1130

Griffiths RP, Caldwell BA, Eroich WA, Morita RY (1983) Microbial processes relating to carbon cycling in southeastern Bering Sea sediments. Mar Ecol Prog Ser 10:265-275

Gunnarsson LAH, Rönnow PH (1982) Interrelationships between sulfate-reducing and methane-producing bacteria in coastal sediments with intense sulfide production. Mar Biol 69:121-128

Heyer J (1990) Der Kreislauf des Methans. Akademie-Verlag. Berlin

Heyer J, Berger U, Suckow R (1990) Methanogenesis in different parts of a bracksh water ecosystem. Limnologica 20:135-139

Heyer J, Suckow R (1985) Okologische Untersuchungen der Methanoxidation in einem sauren Moorsee. Limnologica 16:247-266

Iversen $N_{1}$ Jørgensen BB (1985) Anaerobic methane oxidation rates at the sulfate-methane transition in marine sediments from Kattegat and Skagerrak (Denmark). Limnol Oceanogr 30:944-955

King GM, Klug MJ, Lovley DR (1983) Metabolism of acetate, methanol, and methylated amines in intertidal sediments of Lowes Cove, Maine. Appl environ Microbiol 45: 1848-1853

Kuivila KM, Murray JW, Devol AH (1990) Methane production in the sulfate-depleted sediments of two marine basins. Geochim cosmochim Acta 54:403-411

Lein AYu, Namsaraev BB, Trotsyuk VYa, Lvanov MV (1981) Bacterial methanogenesis in holocene sediments of the Baltic Sea. Geomicrobio]. J 2:299-315

Lerman A (1979) Geochemical processes. Water and sedument environments. Wiley, New York

Martens CS, Berner RA (1977) Interstitial water chemistry of Long Island Sound sediments. I. Dissolved gases. Limnol Oceanogr 22:10-25

Oremland RS, Marsh LS, Polcin S (1982) Methane productron and simultaneous sulphate reduction in anoxic, salt marsh sediments. Nature 296:143-145 
Pollehne F (1986) Benthic nutrient regeneration processes in different sediment types of Kiel Bight. Ophelia 26: $359-368$

Reeburgh WS (1976) Methane consumption in Cariaco Trench waters and sediments. Earth planet Sci Lett 28: 337-344

Sahores JJ, Witherspoon PA (1970) Diffusion of light paraffin hydrocarbons in water from $2^{\circ} \mathrm{C}$ to $80^{\circ} \mathrm{C}$. In: Advances in organic chemistry. Pergamon, Oxford, p 219-230

This article was presented by G. Rheinheimer (Senior Editorial Advisor), Kiel, Germany
Smetacek $V$, von Bodungen B, Knoppers B, Peinert R, Pollehne F. Stegmann P. Zeitzschel B (1984) Seasonal stages charactenzing the annual cycle of an inshore pelagic system. Rapp P-v Réun Cons int Explor Mer 183:126-135

Whiticar MJ (1982) The presence of methane bubbles in the acoustically turbid sediments of Eckernförder Bay, Baltic Sea. In: Manheim FT, Fanning KA (eds) Dynamic environment of the ocean floor. Lexing ton Books, Heath, MA, p 219-235

Manuscript first received: January 10, 1995

Revised version accepted: July 28, 1995 